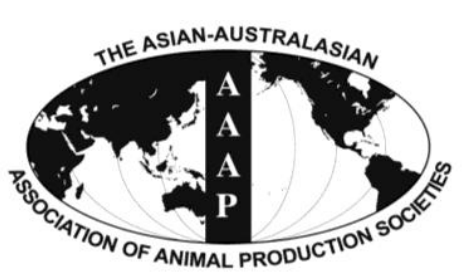

\begin{tabular}{c} 
Open Access \\
$\begin{array}{c}\text { Asian Australas. J. Anim. Sci. } \\
\text { Vol. 27, No. 1 : 55-61 January } 2014 \\
\text { http://dx.doi.org/10.5713/ajas.2013.13307 }\end{array}$ \\
\hline www.ajas.info \\
pISSN 101 1-2367 elSSN 1976-5517
\end{tabular}

\title{
Influence of Protein and Energy Level in Finishing Diets for Feedlot Hair Lambs: Growth Performance, Dietary Energetics and Carcass Characteristics
}

\author{
F. G. Ríos-Rincón, A. Estrada-Angulo, A. Plascencia ${ }^{1}$, M. A. López-Soto ${ }^{1}$, B. I. Castro-Pérez, \\ J. J. Portillo-Loera, J. C. Robles-Estrada, J. F. Calderón-Cortes ${ }^{\mathbf{1}}$, and H. Dávila-Ramos* \\ Facultad de Medicina Veterinaria y Zootecnia, Universidad Autónoma de Sinaloa, Culiacán, 80246 México
}

\begin{abstract}
Forty-eight Pelibuey $\times$ Katahdin male intact lambs $(23.87 \pm 2.84 \mathrm{~kg})$ were used in an $84-\mathrm{d}$ feeding trial, with six pens per treatment in a $2 \times 2$ factorial design arrangement. The aim of the study was to evaluate the interaction of two dietary energy levels (3.05 and $2.83 \mathrm{Mcal} / \mathrm{kg} \mathrm{ME}$ ) and two dietary protein levels (17.5\% and 14.5\%) on growth performance, dietary energetics and carcass traits. The dietary treatments used were: i) High protein-high energy (HP-HE); ii) High protein-low energy (HP-LE); iii) Low protein-high energy (LP-HE), and iv) Low protein-low energy (LP-LE). With a high-energy level, dry matter intake (DMI) values were $6.1 \%$ lower in the low-protein diets, while with low-energy, the DMI values did not differ between the dietary protein levels. Energy levels did not influence the final weight and average daily gain (ADG), but resulted in lower DMI values and higher gain efficiencies. No effects of protein level were detected on growth performance. The observed dietary net energy (NE) ratio and observed DMI were closer than expected in all treatments and were not affected by the different treatments. There was an interaction $(\mathrm{p}<0.03)$ between energy and protein level for kidney-pelvic and heart fat $(\mathrm{KPH}), \mathrm{KPH}$ was higher in lambs fed high energy and high protein diet but not in high energy and low protein diet. The KPH was increased $(20.2 \%, \mathrm{p}=0.01)$ in high-energy diets, while fat thickness was increased $(21.7 \%$, $\mathrm{p}$ $=0.02$ ) in high-protein diets. Therefore, it is concluded that dietary energy levels play a more important role in feed efficiency than protein levels in finishing lambs with a high-energy diet (>2.80 Mcal $/ \mathrm{kg} \mathrm{ME).} \mathrm{Providing} \mathrm{a} \mathrm{level} \mathrm{of} \mathrm{protein} \mathrm{above} 14.5 \%$ does not improves growth-performance, dietary energetics or carcass dressing percentage. (Key Words: Energy Intake, Carcass Composition, Feedlot Hair Sheep, Growth Performance, Productive Response)
\end{abstract}

\section{INTRODUCTION}

The amount of tissues deposited as carcass components is largely determined by the level of protein intake and the energy available for retention in muscle (Baracos, 2005). However, the relationship between energy and protein concentration within the diet is not completely elucidated in lambs. It is thought that, in low-to-moderate energy diets $(<2.50 \mathrm{Mcal} / \mathrm{kg} \mathrm{ME})$, the extra-caloric effect of the

\footnotetext{
* Corresponding Author: H. Dávila-Ramos. Tel: +52-667-718 1850, Fax: +52-667-7181850, E-mail: davila-ramos@uas.edu.mx

1 Instituto de Investigaciones en Ciencias Veterinarias, Universidad Autónoma de Baja California, Mexicali 21386, México.

Submitted May 31, 2013; Accepted Jul. 23, 2013; Revised Sept. 14, 2013
}

increased metabolizable protein intake due to increased protein levels in the diet is likely to be shown by a greater dry matter intake (DMI), a higher average daily gain (ADG) and an increase in the performance of lambs (Muwalla et al., 1998). Moreover, some reports indicate that lambs fed highenergy diets ( $>2.80 \mathrm{Mcal} / \mathrm{kg} \mathrm{ME}$ ) with an increased protein level above $14 \%$ have not shown an advantage in growth performance (Beauchemin et al., 1995), but the body composition of lambs can be modified (NRC, 2007). However, the latter can be affected by the potential for growth (breed), the initial weight at fattening, the number of days on feed and/or the weight at harvest (Cannas et al., 2004). Although breeders have introduced Dorper, Katahdin and Saint Croix sheep breeds to the country of México in recent years, Pelibuey lamb breeds and their crosses 
continue to be the most representative genotype, and have made an important contribution to the persistence of Mexican lambs (Partida and Martínez, 2010). Pelibuey lambs and their crosses are usually offered growingfinished diets that contain between 2.8 and $3.0 \mathrm{Mcal} / \mathrm{kg}$ of ME and $17 \%$ to $18 \%$ of crude protein. At fattening, hairy lambs and their crosses have shown some differences in growth rate and carcass composition in respect to other breeds (Partida and Martínez, 2009; Ruiz-Nuño et al., 2009). However, very little information is presently available regarding the relationship between protein levels in high energy diets on growth performance and carcass characteristics in finishing hairy lambs.

The objective of this experiment was to evaluate the growth performance, dietary energetics, and carcass characteristics in lambs fed two energy concentrations in a finishing diet (3.05 and $2.83 \mathrm{Mcal} / \mathrm{kg} \mathrm{ME})$ at two protein levels $(17.5 \%$ and $14.5 \% \mathrm{CP})$.

\section{MATERIALS AND METHODS}

This trial was conducted at Universidad Autónoma de Sinaloa Feedlot Lamb Research Unit, located in Culiacán, México $\left(24^{\circ} 46^{\prime} 13^{\prime \prime} \mathrm{N}\right.$ and $\left.107^{\circ} 21^{\prime} 14^{\prime \prime} \mathrm{W}\right)$. Culiacán is about $55 \mathrm{~m}$ above sea level, and has a tropical climate. All procedures involving animal care and management were in accordance with and approved by the Universidad Autónoma de Sinaloa Animal Use and Care Committee.
Sixty Pelibuey $\times$ Katahdin lambs were received at the research facility 7 weeks before the start of the trial. Upon arrival, lambs were weighed, treated for endoparasites (Tasasel 5\%, Fort Dodge, Animal Health, México), and injected with $1 \times 10^{6} \mathrm{IU}$ of vitamin A (Synt-ADE, FortDodge, Animal Health, México). During a 35-d adaptation period all lambs received a diet containing (DM basis, g/ $/ \mathrm{kg}$ ): alfalfa hay, 150; ground grain corn, 555; soybean meal, 200; cane molasses, 70; mineral supplement, 25. Following a 7 wk receiving-evaluation period, 48 lambs, initial weight (IW) $(23.8 \pm 2.84 \mathrm{~kg})$, were selected from the original group of 60 lambs for use in the study, based on uniformity of weight and general condition. Upon initiation of the trial, lambs were weighed before their morning meal using an electronic scale (TORREY TIL/S: 107-2691, TOR REY electronics Inc, Houston TX, USA), and were assigned within 6 weight groupings to 24 pens (4 pens/treatment), with 2 lambs/pen. Pens were $6 \mathrm{~m}^{2}$ with overhead shade, automatic waterers and $1 \mathrm{~m}$ fence-line feed bunks. To evaluate the interaction of two dietary energy levels (3.05 and $2.83 \mathrm{Mcal} / \mathrm{kg} \mathrm{ME}$ ) and two dietary protein levels (17.5\% and $14.5 \%$ ), lamb groups were fed one of four of the next experimental diets over 84 days (Table 1 ) in a $2 \times 2$ factorial design arrangement: i) High protein-high energy diet (HP-HE); ii) High protein-low energy diet (HP-LE); iii) Low protein-high energy diets (LP-HE), and iv) Low protein-low energy diets (LP-LE). Lambs were weighed before the morning meal on $\mathrm{d} 1$ and 84 (harvest). Lambs

Table 1. Ingredients and composition of the experimental diets (DM)

\begin{tabular}{|c|c|c|c|c|}
\hline \multirow{2}{*}{$\begin{array}{l}\text { Ingredients } \\
\text { (\% of DM basis) }\end{array}$} & \multicolumn{4}{|c|}{ Treatments } \\
\hline & HPHE & HPLE & LPHE & LPLE \\
\hline Cracked corn & 59.00 & 50.50 & 66.00 & 56.00 \\
\hline Soybean meal & 18.50 & 19.00 & 11.50 & 12.00 \\
\hline Sudan hay & 10.00 & 20.00 & 10.00 & 21.50 \\
\hline Molasses cane & 8.0 & 8.0 & 8.0 & 8.0 \\
\hline Tallow & 2.0 & 0.0 & 2.0 & 0.0 \\
\hline Mineral premix & 2.5 & 2.5 & 2.5 & 2.5 \\
\hline \multicolumn{5}{|l|}{ Calculated analisis } \\
\hline Metabolizable energy (Mcal/kg) & 3.05 & 2.83 & 3.05 & 2.83 \\
\hline \multicolumn{5}{|l|}{ Net energy $(\mathrm{Mcal} / \mathrm{kg})$} \\
\hline Maintenenace & 2.07 & 1.89 & 2.08 & 1.89 \\
\hline Gain & 1.41 & 1.26 & 1.42 & 1.26 \\
\hline Crude protein $(\%)$ & 17.28 & 17.53 & 14.45 & 14.68 \\
\hline Rumen undegradable protein $(\%)$ & 37.98 & 36.82 & 39.49 & 37.86 \\
\hline Ether extract $(\%)$ & 4.85 & 2.71 & 5.02 & 2.82 \\
\hline $\operatorname{NDF}(\%)$ & 15.73 & 21.48 & 15.44 & 22.02 \\
\hline Calcium (\%) & 0.76 & 0.82 & 0.74 & 0.81 \\
\hline Phosphorous (\%) & 0.35 & 0.36 & 0.32 & 0.33 \\
\hline
\end{tabular}


were fed twice daily at 09:00 and 15:00 $\mathrm{h}$ in a 30:70 proportion (as a feed basis). Feed bunks were evaluated visually before feeding between 08:40 and 08:50 h each morning to determine the quantity of feed remaining from the previous day. Daily feed allotments to each pen was adjusted to allow for minimal $(<5 \%)$ feed accumulation. Adjustments (increase or decrease) in daily feed delivery were allotted to the afternoon feeding. Feed samples were collected on a daily basis for DM analysis (forced-air oven; AOAC, 2000). Assuming that the DMI intake is related to energy requirements and dietary $\mathrm{NE}_{\mathrm{m}}$, it is expected that the DMI can be estimated from average ADG and LW values according to the following equation: DMI, $\mathrm{kg} / \mathrm{d}=$ $\left(\mathrm{EM} / \mathrm{NE}_{\mathrm{m}}\right)+\left(\mathrm{EG}_{\mathrm{EN}}\right)$, where $\mathrm{ME}$ (energy required for maintenance, $\mathrm{Mcal} / \mathrm{d})=0.056 \times \mathrm{SBW}^{0.75}(\mathrm{NRC}, 1985), \mathrm{EG}$ (energy gain, $\mathrm{Mcal} / \mathrm{d})=0.276 \times \mathrm{ADG} \times \mathrm{SBW}^{0.75}(\mathrm{NRC}, 1985)$, and $\mathrm{NE}_{\mathrm{m}}$ and $\mathrm{NE}_{\mathrm{g}}$ are 2.05 and $1.40 \mathrm{Mcal} / \mathrm{kg}$, respectively (derived from tabular values based on ingredient composition of the experimental diet; NRC, 1985). The coefficient of 0.276 was estimated assuming a mature weight for Pelibuey $\times$ Kathdin male lambs of $113 \mathrm{~kg}$ (Canton and Quintal, 2007). Dietary NE were estimated by means of the quadratic formula: $x=\frac{-b \pm \sqrt{b^{2}-4 a c}}{2 c}$, where $x=\mathrm{NE}_{\mathrm{m}}$, $\mathrm{a}=-0.41 \mathrm{EM}, \mathrm{b}=0.877 \mathrm{EM}+0.41 \mathrm{DMI}+\mathrm{EG}$, and $\mathrm{c}=-0.877$ DMI (Zinn et al., 2008).

Hot carcass weights (HCW) were obtained for all lambs at the time of slaughter. Because feed and water were not withdrawn for $12 \mathrm{~h}$ before weighing and slaughtering, the initial and final weights were reduced (pencil shrink) by $4 \%$ to account for digestive tract fill (Cannas et al., 2004). After carcasses were chilled for $24 \mathrm{~h}$ at $4^{\circ} \mathrm{C}$ the carcass cold weight (CCW) was recorded and the following measurements were obtained: i) Fat thickness over the 12th rib, perpendicular to the Longissimus dorsi (LM) with a
Vernier Caliper (Digital King, foot of 6", Mexico City), ii) LM area, between 12 to 13th rib was measured using a plastic grid and iii) kidney, pelvic and heart fat (KPH), which was removed from the hind saddle and weighed and reported as a percentage of carcass weight (USDA, 1982). Each carcass was split in half. The right side was merchandised, while the left side was fabricated into wholesale cuts, without trimming, according to the North American Meat Processors Association guidelines (NAMP, 1997), with each cut dissected into the lean components, bone and fat. Components were weighed and the total weights of muscle, fat and bone were expressed in percentages in relation to the cold carcass weight.

Performance (gain, feed efficiency, dietary energetics) and carcass data were analyzed using a randomized complete block design using the MIXED procedure of the SAS Institute (2004) for a randomized complete block design. This design was arranged as a $2 \times 2$ factorial experiment, with two levels of energy (3.05 and 2.83 $\mathrm{Mcal} / \mathrm{kg} \mathrm{ME}$ ) and two levels of protein (17.5\% and 14.5\%), using pens as an experimental unit. The fixed effect consisted of treatment, and the random effect was the pen. Carcass composition data were analyzed using the MIXED model procedures (SAS Institute, 2004), including the fixed main effect of treatment and the random effect of individual carcass. Treatment effects were tested as follows: i) Energy level, ii) protein level, and iii) energy $\times$ protein interaction. Contrasts were considered significant when the $\mathrm{p}$-value was $\leq 0.05$, and tendencies were identified when the $p$-value was between 0.05 and 0.10 .

\section{RESULTS AND DISCUSSION}

The treatments effects on the growth performance of finishing lambs are shown in Table 2. There was an

Table 2. Influence of protein and energy level on growth performance of feedlot hair lambs

\begin{tabular}{|c|c|c|c|c|c|c|c|c|c|c|c|c|}
\hline \multirow{3}{*}{ Item } & \multicolumn{4}{|c|}{ Energy level (Mcal ME/kg) } & \multirow[b]{3}{*}{ SEM } & \multicolumn{4}{|c|}{ Main effects } & & & \\
\hline & \multicolumn{2}{|c|}{3.05} & \multicolumn{2}{|c|}{2.83} & & \multicolumn{2}{|c|}{$\begin{array}{c}\text { Energy level } \\
\text { (Mcal ME/kg) }\end{array}$} & \multicolumn{2}{|c|}{$\begin{array}{c}\text { Protein } \\
\text { level }(\%)\end{array}$} & \multicolumn{3}{|c|}{ p-value } \\
\hline & $\begin{array}{c}17.5 \% \\
\mathrm{CP}\end{array}$ & $\begin{array}{c}14.5 \% \\
\mathrm{CP}\end{array}$ & $\begin{array}{c}17.5 \% \\
\mathrm{CP}\end{array}$ & $\begin{array}{c}14.5 \% \\
\mathrm{CP}\end{array}$ & & 3.05 & 2.83 & 17.5 & 14.5 & $\mathrm{E}$ & $\mathrm{P}$ & $\mathrm{E} \times \mathrm{P}$ \\
\hline \multicolumn{13}{|l|}{ Body weigth (kg) } \\
\hline Initial & 23.07 & 22.69 & 23.15 & 22.79 & 1.22 & 22.88 & 22.97 & 23.11 & 22.74 & 0.76 & 0.23 & 0.97 \\
\hline Final & 47.49 & 43.97 & 47.45 & 46.78 & 1.74 & 45.73 & 47.11 & 47.47 & 45.37 & 0.26 & 0.10 & 0.25 \\
\hline DM intake $(\mathrm{g} / \mathrm{d})$ & $1.222^{\mathrm{ab}}$ & $1.084^{\mathrm{b}}$ & $1.333^{\mathrm{a}}$ & $1.328^{\mathrm{a}}$ & 0.050 & $1.153^{\mathrm{a}}$ & $1.331^{\mathrm{b}}$ & 1.278 & 1.210 & $<0.01$ & 0.08 & 0.10 \\
\hline DMI (\% BW) & $3.47^{\mathrm{a}}$ & $3.26^{\mathrm{b}}$ & $3.78^{\mathrm{c}}$ & $3.82^{\mathrm{c}}$ & 0.06 & $3.36^{\mathrm{a}}$ & $3.80^{\mathrm{b}}$ & 3.62 & 3.54 & $<0.01$ & 0.17 & 0.03 \\
\hline $\operatorname{ADG}(\mathrm{kg} / \mathrm{d})$ & 0.291 & 0.253 & 0.289 & 0.286 & 0.012 & 0.272 & 0.287 & 0.290 & 0.269 & 0.23 & 0.12 & 0.19 \\
\hline Feed for gain & 4.22 & 4.32 & 4.60 & 4.66 & 0.14 & $4.27^{\mathrm{a}}$ & $4.63^{b}$ & 4.41 & 4.49 & $<0.01$ & 0.53 & 0.88 \\
\hline Gain for feed & 0.238 & 0.234 & 0.218 & 0.216 & 0.218 & $0.236^{\mathrm{a}}$ & $0.217^{\mathrm{b}}$ & 0.228 & 0.225 & $<0.01$ & 0.64 & 0.92 \\
\hline
\end{tabular}

$\mathrm{SEM}=$ Standard error mean; $\mathrm{E}=$ Energy $\mathrm{P}=$ Protein $\mathrm{E} \times \mathrm{P}=$ Energy and Protein levels interaction .

Initial and final BW were reduced $4 \%$ to account for fill.

${ }^{a, b, c}$ Different letters in the same variable indicate statistical differences $(p \leq 0.05)$. 
interaction $(\mathrm{p}=0.03)$ between energy levels and protein levels on the DMI (as percentage of BW). With the highenergy diet, the DMI values were $6.1 \%$ lower than with low-protein diets, while with the low-energy diets, the DMI did not differ between proteins levels. In the same manner, Fluharty and McClure (1997) observed lower (12.4\%) intakes in lambs when protein levels of $14.3 \%$ and $18.9 \%$ were compared in a similar high-energy diet $(2.80 \mathrm{Mcal}$ $\mathrm{NEm} / \mathrm{kg}$ ) as used in the present study.

Lambs fed a high-energy diet had a lower DM intake (13.4\%) than the low-energy diet group. This finding is in agreement with the principle that feed intake is regulated by dietary energy density in ruminants. ME intake, rather than physical fill, appeared to be the dominant factor influencing the DMI for the diets investigated. Lu and Potchoiba (1990), observed a curvilinear response when comparing 3 levels of energy $(2.46,2.77$, and $3.05 \mathrm{Mcal} / \mathrm{kg}$ ME DM) in diets. In a study by Lu and Potchoiba (1990), the maximal DMI was observed in the medium-energy diet $(2.77 \mathrm{Mcal} / \mathrm{kg} \mathrm{ME})$, which was similar to the energy concentration of 2.83 $\mathrm{Mcal} / \mathrm{kg}$ ME tested in the present study. The energy level did not influence ADG ( $\mathrm{p} \geq 0.23)$, however, the lambs fed high-energy diets showed an increase in gain to feed $(8.1 \%)$ as a consequence of differences in DM intake. Increases in feed efficiency have been a common response when comparing high-energy and low-energy diets (NRC, 2007; Kioumarzi et al., 2008; Adbel-Basset, 2009). However, the effect of increased dietary energy levels on ADG has been less consistent. In some instances (Craddock et al., 1974; Lu and Potchoiba, 1990; García et al., 2003), increasing the energy level had no effect on the ADG, whereas in others (Kioumarzi et al., 2008; Adbel-Basset, 2009), an increase in energy level markedly increased the ADG. In most cases, when growth performance was compared among dietary energy concentrations below $2.6 \mathrm{Mcal} / \mathrm{kg} \mathrm{ME}$, the ADG and feed efficiency increased as energy increased. However when the energy concentration is above of $2.8 \mathrm{Mcal} / \mathrm{kg} \mathrm{ME}$, feed efficiency increases with increased energy level without any differences in the ADG ( $\mathrm{Lu}$ and Potchoiba, 1990; García et al., 2003). The latter could be partially explained by the inverse relationship between DMI and the dietary energy density observed in both the current study and those previous studies, as well as for the composition of gain observed generally in lambs fed higher energy diets (Jindal et al., 1980; Cannas et al., 2004).

The high-protein level group tended to have greater final weights and DMI than those fed low-protein diets $(\mathrm{p}=$ 0.10 ). However, the protein level did not affect the ADG or feed for gain. Some reports indicate that levels of protein play an important role on DM intake and ADG in lambs. This is particularly true when the studies included protein levels below 14\%. For example, Lu and Potchoiba (1990) reported that the DM intake and ADG was influenced by dietary CP level $(12,13$, and $15 \% \mathrm{CP})$ in a linear fashion in growing goats. Kaya et al. (2009) observed no differences in the DMI, $\mathrm{ADG}$ or GF when $13 \%$ and $16 \%$ CP levels were compared, yet the lambs that were fed the $10 \% \mathrm{CP}$ diet had lower DMI, ADG and GF values than those fed $13 \%$ and $16 \%$ CP diets. In the same manner, Javed et al. (2010) reported a greater DM intake and ADG in Thalli male growing lambs that were fed a diet containing $14 \%$ of CP compared to those fed a $12 \% \mathrm{CP}$ diet. It is thought that when the protein supply exceeds the requirement, energy becomes limiting for growth, and the animals no longer respond to additional intakes of protein (Titgemeyer, 2003). In this sense, Rocha et al. (2004) did not observe an effect of protein level $(14,16,18$, and $20 \% \mathrm{CP})$ on DM intake, gain and feed efficiency. Beauchemin et al. (1995) and Ruiz-Nuño et al. (2009) concluded that the protein level has a minor effect on lamb performance with regards to wool or hair sheep when finishing diets contained more than $14 \%$ of crude protein. Our findings, thus, agree with these authors.

The effects of treatments on dietary NE and observedto-expected DMI ratios are shown in Table 3. No

Table 3. Influence of protein and energy level on dietary energy and observed to expected DMI of feedlot hair lambs

\begin{tabular}{|c|c|c|c|c|c|c|c|c|c|c|c|c|}
\hline \multirow{3}{*}{ Item } & \multicolumn{4}{|c|}{ Energy level (Mcal ME/kg) } & \multicolumn{5}{|c|}{ Main effects } & & & \\
\hline & \multicolumn{2}{|c|}{3.05} & \multicolumn{2}{|c|}{2.83} & \multirow[b]{2}{*}{ SEM } & \multicolumn{2}{|c|}{$\begin{array}{l}\text { Energy level } \\
\text { (Mcal ME/kg) }\end{array}$} & \multicolumn{2}{|c|}{$\begin{array}{c}\text { Protein level } \\
(\%)\end{array}$} & \multicolumn{3}{|c|}{$\mathrm{p}$-value } \\
\hline & $\begin{array}{c}17.5 \% \\
\mathrm{CP}\end{array}$ & $\begin{array}{c}14.5 \% \\
\mathrm{CP}\end{array}$ & $\begin{array}{c}17.5 \% \\
\mathrm{CP}\end{array}$ & $\begin{array}{c}14.5 \% \\
\mathrm{CP}\end{array}$ & & 3.05 & 2.83 & 17.5 & 14.5 & $\mathrm{E}$ & $\mathrm{P}$ & $\mathrm{E} \times \mathrm{P}$ \\
\hline \multicolumn{13}{|l|}{ NE diet (Mcal/kg) } \\
\hline Maintenance & 2.05 & 2.03 & 1.91 & 1.88 & 0.04 & $2.04^{\mathrm{a}}$ & $1.89^{\mathrm{b}}$ & 1.98 & 1.95 & $<0.01$ & 0.51 & 0.96 \\
\hline Gain & 1.39 & 1.37 & 1.26 & 1.24 & 0.03 & $1.38^{\mathrm{a}}$ & $1.25^{\mathrm{b}}$ & 1.33 & 1.30 & $<0.01$ & 0.51 & 0.96 \\
\hline \multicolumn{13}{|l|}{ Obs to exp NE } \\
\hline Maintenance & 0.99 & 0.98 & 1.01 & 0.99 & 0.02 & 0.98 & 1.00 & 1.00 & 0.99 & 0.33 & 0.51 & 0.93 \\
\hline Gain & 0.98 & 0.97 & 1.00 & 0.99 & 0.02 & 0.97 & 1.00 & 0.99 & 0.98 & 0.34 & 0.57 & 0.99 \\
\hline Obs to exp DMI & 1.01 & 1.04 & 0.99 & 1.00 & 0.02 & 1.02 & 1.00 & 1.00 & 1.02 & 0.24 & 0.46 & 0.87 \\
\hline
\end{tabular}

$\mathrm{SEM}=$ Standard error mean $; \mathrm{E}=$ Energy $; \mathrm{P}=$ Protein $; \mathrm{E} \times \mathrm{P}=$ Energy and protein levels interaction .

Initial and final BW were reduced $4 \%$ to account for fill.

${ }^{a, b, c}$ Different letters in the same variable indicate statistical differences $(\mathrm{p} \leq 0.05)$. 
interactions were detected between energy and protein levels.

Across the entire $84 \mathrm{~d}$ period, the average observed-toexpected DMI of lambs was $101 \%$ of the expected value, based on tabular (NRC, 2007) estimates of dietary energy density and observed SBW and ADG values (Table 3), supporting the practicality of the prediction equations proposed by the NRC (1985) for the estimation of DMI in relation to SBW and ADG in feedlot lambs. In the same manner, the observed-to-expected NE diet averaged 0.99 . This supports the theory that there was no synergistic effect resulting in a more efficient use of energy in the diet at the levels of energy and protein evaluated in this study. The extra-caloric effect of increased metabolizable protein intake due to increased protein levels in the diet could be expected in animals with high rates of growth and/or with a limited intake. Milis and Liamadis (2008) observed that CP levels above $14 \%$ in finishing diets do not affect the energy value of sheep rations, irrespective of the CP level. However, this study suggested that when the CP content is high, $\mathrm{N}$ degradability should be low otherwise the ME of rations is negatively affected. The percentages of rumen degradable protein (RDP) in the experimental diets used in this study were very similar among the diets and averaged $38 \pm 1.09 \%$. Moreover, the results obtained here related to the observed-to-expected NE diet confirms that dietary effects on growth performance were mainly due to energy concentrations rather than levels of $\mathrm{CP}$.

Treatment effects on the carcass characteristics and carcass composition of lambs are shown in Table 4 . There was only an interaction identified between energy level and protein level for the kidney-pelvic fat $(\mathrm{KPH})$ percentage ( $\mathrm{p}$ $=0.03$ ). With the high-energy and high-protein diet, KPH values were $22 \%$ greater than low-protein and low-energy diet. In contrast, in low energy diets there were no differences $(p>0.05)$ in KPH proportion between protein levels.

In agreement with previous reports (Beuchemin et al., 1995; Rocha et al., 2004), the energy level, in high-energy finishing diets, only had small effects on HCW and dressing percentage. While, an increase of visceral fat as a result of increases of the energy density of a diet is a common response in fattening lambs (Hegarty et al., 2006; AbdelNaset, 2009). Increasing the energy level of 2.83 to 3.05 increased the visceral fat $(20.2 \%, p=0.01)$. This increase of visceral fat is in agreement with Partida and Martinez (2010), who reported an increase of $17.1 \%$ of visceral fat when compared two energy levels (2.60 vs $2.80 \mathrm{Mcal} / \mathrm{kg}$ $\mathrm{ME}$ ) in finishing Pelibuey lambs.

In agreement with previous reports (Beuchemin et al., 1995; Ruiz-Nuño et al., 2009), the protein level, in highenergy finishing diets, only had small effects on HCW, dressing percentage or KPH. Increasing the protein level of $14.5 \%$ to $17.5 \%$ increased the back fat thickness $(22.2 \%, \mathrm{p}$ = 0.02). Similarly, data from Ruiz-Nuño et al. (2009) show a linear increase of backfat thickness $(1.42,2.10$, and 2.18 $\mathrm{mm}$ ) in Pelibuey lambs when they were fed with 14,16 , and $18 \%$ of $\mathrm{CP}$ in high energy diets $(2.80 \mathrm{Mcal} / \mathrm{kg} \mathrm{ME})$. In contrast, Ebrahimi et al. (2007) did not observe any effects of protein level $(10.5,12.5$, and 14.5\%) on back fat

Table 4. Influence of protein and energy level on carcass characteristics and carcass composition of feedlot hair lambs

\begin{tabular}{|c|c|c|c|c|c|c|c|c|c|c|c|c|}
\hline \multirow{3}{*}{ Item } & \multicolumn{4}{|c|}{ Energy level (Mcal ME/kg) } & \multicolumn{5}{|c|}{ Main effects } & & & \\
\hline & \multicolumn{2}{|c|}{3.05} & \multicolumn{2}{|c|}{2.83} & \multirow[b]{2}{*}{ SEM } & \multicolumn{2}{|c|}{$\begin{array}{l}\text { Energy level } \\
\text { (Mcal ME/kg) }\end{array}$} & \multicolumn{2}{|c|}{$\begin{array}{c}\text { Protein level } \\
(\%)\end{array}$} & \multicolumn{3}{|c|}{ p-value } \\
\hline & $\begin{array}{c}17.55 \% \\
\mathrm{CP}\end{array}$ & $\begin{array}{c}14.5 \% \\
\mathrm{CP}\end{array}$ & $\begin{array}{c}17.5 \% \\
\mathrm{CP}\end{array}$ & $\begin{array}{c}14.5 \% \\
\mathrm{CP}\end{array}$ & & 3.05 & 2.83 & 17.5 & 14.5 & $\mathrm{E}$ & $\mathrm{P}$ & $\mathrm{E} \times \mathrm{P}$ \\
\hline Final shrunk wt (kg) & 47.49 & 43.97 & 47.45 & 46.78 & 1.74 & 45.73 & 47.12 & 47.47 & 45.37 & 0.26 & 0.09 & 0.25 \\
\hline Hot carcass wt (kg) & 25.02 & 23.74 & 24.91 & 24.79 & 1.00 & 24.39 & 24.84 & 24.97 & 24.27 & 0.47 & 0.28 & 0.37 \\
\hline Chilled carcass wt (kg) & 25.23 & 23.06 & 24.07 & 24.39 & 0.96 & 23.64 & 24.22 & 24.15 & 23.72 & 0.32 & 0.46 & 0.21 \\
\hline Dressing percentage $\mathrm{HCW}$ & 51.00 & 52.45 & 50.76 & 52.13 & 0.76 & 51.72 & 51.45 & 50.88 & 52.30 & 0.72 & 0.08 & 0.96 \\
\hline Dressing percentage $\mathrm{CCW}$ & 52.63 & 53.99 & 52.51 & 52.97 & 0.56 & 53.31 & 52.73 & 52.58 & 53.48 & 0.27 & 0.10 & 0.40 \\
\hline $\mathrm{LM}$ area $\left(\mathrm{cm}^{2}\right)$ & 11.52 & 11.41 & 11.60 & 12.21 & 0.60 & 11.47 & 11.91 & 11.56 & 11.81 & 0.47 & 0.67 & 0.55 \\
\hline Kidney-pelvic fat (\%) & $4.38^{b}$ & $3.41^{\mathrm{a}}$ & $3.03^{\mathrm{a}}$ & $3.19^{\mathrm{a}}$ & 0.29 & $3.90^{\mathrm{b}}$ & $3.11^{\mathrm{a}}$ & 3.70 & 3.30 & $<0.01$ & 0.10 & 0.03 \\
\hline Fat thickness $(\mathrm{cm})$ & 2.10 & 1.54 & 1.86 & 1.54 & 0.20 & 1.82 & 1.70 & $1.98^{b}$ & $1.55^{\mathrm{a}}$ & 0.46 & 0.02 & 0.45 \\
\hline \multicolumn{13}{|l|}{ Carcass composition $(\%)$} \\
\hline Muscle & 57.95 & 58.06 & 57.38 & 58.92 & 1.47 & 58.00 & 58.13 & 57.66 & 58.49 & 0.72 & 0.62 & 0.61 \\
\hline Fat & 23.13 & 23.44 & 23.40 & 22.69 & 0.02 & 23.28 & 23.06 & 23.27 & 23.07 & 0.95 & 0.49 & 0.36 \\
\hline Bone & 18.92 & 18.50 & 19.22 & 18.38 & 0.54 & 18.71 & 18.81 & 19.07 & 18.44 & 0.67 & 0.04 & 0.20 \\
\hline Muscle:fat ratio & 2.51 & 2.48 & 2.45 & 2.59 & 0.23 & 2.49 & 2.52 & 2.48 & 2.54 & 0.93 & 0.69 & 0.57 \\
\hline Muscle:bone ratio & 3.06 & 3.14 & 2.99 & 3.21 & 0.15 & 3.10 & 3.09 & 3.02 & 3.17 & 0.42 & 0.22 & 0.64 \\
\hline
\end{tabular}

$\mathrm{SEM}=$ Standard error mean. $\mathrm{E}=$ Energy; $\mathrm{P}=$ Protein; $\mathrm{E} \times \mathrm{P}=$ Energy and Protein levels interaction.

${ }^{\mathrm{a}, \mathrm{b}}$ Different letters in the same variable indicate statistical differences $(\mathrm{p} \leq 0.05)$. 
thickness in Mehraban lambs fed finishing diets contained moderated energy level $(2.50 \mathrm{Mcal} / \mathrm{kg} \mathrm{ME})$. The increase $(\mathrm{p}<0.05)$ in back fat thickness promoted by the high protein level in high energy diets is a reflection of the excess of protein directed toward into fat synthesis rather than the production of lean tissue. The latter, can be supported by the absence of changes in rib eye area observed between treatments in the present study.

No interactions were detected between energy and protein levels on carcass composition. Muscle and fat averaged $58.07 \pm 0.47 \%$ and $23.17 \pm 0.24 \%$, respectively, and were not modified by the effects of protein or energy levels. These values are in agreement with values of $55.20 \%$ and $18 \%$ reported by Partida et al. (2009) in Pelibuey $\times$ Dorset animals that were fed with a diet containing $2.80 \mathrm{Mcal} / \mathrm{kg}$ $\mathrm{ME}$ and harvested at an $\mathrm{LW}$ of $47 \mathrm{~kg}$, but were lower for protein and higher for fat than those values reported of $64.3 \%$ of muscle and $13.8 \%$ of fat obtained in Pelibuey lambs harvested at an LW of $44 \mathrm{~kg}$ (Partida and Martínez, 2010). The differences in carcass composition observed in the present study and those reported by Partida and Martinez (2010) were mainly due to differences in the rate of growth. The average gain observed in the present study was $38 \%$ greater $(280$ vs $177 \mathrm{~g} / \mathrm{d})$ than those seen by Partida and Martínez (2010).

Energy levels did not affect bone percentages, but diets with high protein levels had greater bone percentages than low-protein level diets $(3.3 \%, \mathrm{p}<0.05)$. The reason for this is uncertain, since the bone formation is completed earlier than other tissues in growing animals (Colomer-Rocher et al., 1992), it is conceivable that there were no differences in bone percentages among treatments due to the likelihood of completion of bone formation before this growth trial, thus, these differences in particular may be due to measurement mistakes rather than protein level effect. Muscle:bone and muscle:fat ratios were not affected by the treatments. In contrast, Partida and Martinez (2010) observed that a higher energetic diet promoted the increase of muscle tissue and improved the muscle:fat ratio from 4.66 to 6.00 in Pelibuey lambs which were harvested at an LW of $44 \mathrm{~kg}$.

It is concluded that dietary effects on growth performance and dietary energetics in hairy lambs (initial weight $\sim 22 \mathrm{~kg}$ ) were due mainly to energy concentrations rather than levels of $\mathrm{CP}$ in high energy finishing diets (i.e. $2.80 \mathrm{Mcal} / \mathrm{kg} \mathrm{ME}$ ) with a minimal concentration of $14.5 \%$ protein. Thus, when a single concentrate diet is allocated during the finishing period, there appears to be no advantage to increasing the protein concentration beyond $14.5 \%$. In this type of diets $(>2.80 \mathrm{Mcal} / \mathrm{kg} \mathrm{ME})$, visceral fat deposition is the main nutrient that is affected when lambs are slaughtered at similar weights, while protein and energy levels had small effects on carcass characteristics.

\section{ACKNOWLEDGEMENTS}

The authors are thankful to the SEP-PROMEP for financial support. Project: Integral Development of UASCA-205. Ref \#: 2007-25-41.

\section{REFERENCES}

Abdel-Baset, N. S. 2009. Effect of dietary energy levels on the performance and nutrient digestibility of lambs. Vet. World 2: 418-420.

AOAC. 2000. Official methods of analysis. 17th edn. Association of Official Analytical Chemists, Arlington, Virginia.

Baracos, V. E. 2005. Whole animal and tissue proteolysis. In: Biology of metabolism in growing animals III (Ed. D. G. Burrin and H. J. Mersmann). Elsevier Ltd. Oxford, UK. pp. 69-82.

Beauchemin, K. A., L. A. McClelland, S. D. M. Jones, and G. C. Kozub. 1995. Effects of crude protein content, protein degradability and energy concentration of the diet on growth and carcass characteristics of market lambs fed high concentrate diets. Can. J. Anim Sci. 75:387-395.

Cannas, A., L. O. Tedeschi, D. G. Fox, A. N. Pell, and P. J. Van Soest. 2004. A mechanistic model for predicting the nutrient requirements and feed biological values for sheep. J. Anim. Sci. 82:149-169.

Canton, J. G. and J. A. Quintal. 2007. Evaluation of growth and carcass characteristics of pure Pelibuey sheep and their cross with Dorper and Kathdin breeds. J. Anim Sc. 85(Suppl. 1):581 (Abstr.).

Colomer-Rocher, F., A. H. Kirton, G. J. K. Mercer, and D. M. Duganzich. 1992. Carcass composition of New Zealand Saanen goats slaughtered at different weights. Small Rumin. Res. 7:161-173.

Craddock, B. F., R. A. Field, and M. L. Riley. 1974. Effects of protein and energy levels on lamb carcass composition. J. Anim. Sci. 39:325-330.

Ebrahimi, R., H. R. Ahmadi, M. J. Zamiri, and E. Rowghani. 2007. Effect of energy and protein levels on feedlot performance and carcass characteristics of Mehraban ram lambs. Pakistan J. Biol. Sci. 15:1679-1684.

Fluharty, F. L. and K. E. McClure. 1997. Effects of dietary energy intake and protein concentration on performance and visceral organ mass in lambs. J. Anim. Sci 75:604-610.

Garcia, C. A., C. Costa, A. L. Gomes, M. A. Neres, and G. M. Jordao. 2003. Níveis de energia no desempenho e características da carcaça de cordeiros alimentados em creep feeding. R. Bras. Zootec. 32:1371-1379 (In portuguese).

Hegarty, R. S., C. Shands, R. Marchant, D. L. Hopkins, A. J. Ball, and S. Harden. 2006. Effects of available nutrition and sire breeding values for growth and muscling on the development of crossbred lambs. 1: Growth and carcass characteristics. Aust. J. Agric. Res. 57:593-603.

Javed, S. I., J. Asif, and A. Muhammad. 2010. Nutrient digestibility and feedlot performance of lambs fed diets variying protein and energy content. Trop. Anim. Health Prod. 42:941-946.

Jindal, S. K., A. K. Mehta, and M. V. N. Rao. 1980. Influence of 
dietary energy on the body composition and feed conversion efficiency during growth in goats. Indian J. Nutr. Diet. 17:9598.

Kaya. I., Y. Unal, T. Sahin, and D. Elmali. 2009. Effect of different protein levels on fattening performance, digestibility and rumen parameters in finishing lambs. J. Anim. Vet. Adv. 8: 309-312.

Kioumarzi, H., J. K. Jafari, M. Zahedifar, A. R. Zeidavi, S. Z. Mirhosseini, and M. R. Taherzadeh. 2008. The effect of dietary energy and protein level on performance, efficiency and carcass characteristics of Taleshi lambs. Asian J. Anim. Vet. Adv. 3:307-313.

Lu, C. D. and M. J. Potchoiba. 1990. Feed intake and weight gain of growing goats fed diets of various energy and protein levels. J. Anim. Sci. 68:1751-1759.

Milis, Ch. and D. Liamadis. 2008. Nutrient digestibility and energy value of sheep rations differing in protein level, main protein source and non-forage fibre source. J. Anim. Physiol. Anim. Nutr. 92:44-52.

Muwalla, M. M., M. Y. Harb, and T. F. Crosby. 1998. Effects of lasalocid and protein levels on the performance of Awassi lambs. Small Rumin. Res. 28:15-22.

NAMP. 1997. The meat buyers guide. North American Meat Processor Association, Weimar, TX.

NRC. 1985. Nutrient requirements for sheep. 6th Revised Edn. National Academy Press, Washington, DC.

NRC. 2007. Nutrient requirements of small ruminants. Sheep, Goats, Cervids, and New World Camelids. National Academies Press, Washington, DC.
Partida, P. J. A. and L. R. Martínez. 2010. Body composition in Pelibuey lambs in terms of feed energy concentration and slaughter weight. Rev. Vet. Mex. 41:177-190.

Partida, P. J. A., D. Braña, and L. R. Martínez. 2009. Productive performance and carcass characteristics in Pelibuey sheep and crossbreds (Pelibuey*Suffolk - Dorset). Rev. Mex. Cien.Pec. 47:313-322.

Rocha, M. H. M., I. Susin, A. V. Pires, J. S. Fernández, and C. M. Quirino. 2004. Performance of Santa Inés lambs fed diets of variable crude protein levels. Sci. Agric. 61:141-145.

Ruiz-Nuño, A., J. J. Uribe-Gomez, J. R. Orozco-Hernandez, and V. O. Fuentes-Hernandez. 2009. The effect of protein level concentrations in the diet of fattening Dorper and Pelibuey lambs. J. Anim. Vet. Adv. 8:1049-1051.

SAS Institute. 2004. SAS/STAT: user's guide: Version 9.1. SAS Institute Inc. Cary, North Carolina.

Titgemeyer, E. C. 2003. Amino acid utilization by growing and finishing ruminants. In: Amino acids in Animal Nutrition (Ed. J. P. F. D'Mello). CAB International, Wallingford, UK. pp. 329-346.

USDA, 1982. Official United States standards for grades of carcass lambs, yearling mutton and mutton carcasses. Agriculture Marketing Service, USA.

Zinn, R. A., A. Barreras, F. N. Owens, and A. Plascencia. 2008. Performance by feedlot steers and heifers: Daily gain, mature body weight, dry matter intake, and dietary energetics. J. Anim. Sci. 86:2680-2689. 